\title{
Votes nudge Australia closer to joining telescope project
}

Sydney. Australia's general election, which takes place next week (2 March), may have helped to provide the country's astronomers with an entry ticket to the world's largest optical and infrared telescope, currently under construction in Chile as part of the European Southern Observatory (ESO).

Last December, Australian astronomers were shocked when the government announced that it was not prepared to include a contribution of $\mathrm{A} \$ 28$ million (US\$21 million) over six years to the ESO in a round of major national research facilities announced as part of a broad innovation statement. Seven other projects worth \$A62.4 million over six years were supported (see Nature 378, 653; 1995).

Last week, however, in the middle of an election campaign in which the Labor government's popularity has been trailing that of the should be a priority. conservative coali-

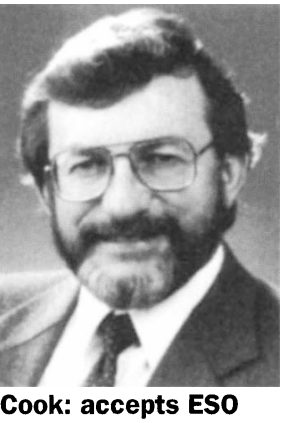

tion of the Liberal and National parties, Peter Cook, the Australian science minister, announced that Australia's membership of the ESO will indeed be a priority within Labor's next budget in August, if re-elected, with increased funding of $A \$ 30$ million over a shorter time-scale of five years.

The ESO project has been under preparation for two years since Australia became the ninth and only non-European nation to be invited to join the consortium. The rejection of funding in December put continuity of the invitation in serious danger.

Australian participation had already received unanimous endorsement from the astronomy community and, despite costing more than other applications for funds, had received top ranking from two expert committees set up by the government.

Furthermore, Australian expertise in optical interferometry is considered especially valuable for the Very Large Telescope (VLT), with its four 8.2-metre mirrors, which is now being built at Cerro Tololo on Mount Paranal in Chile.

If ESO's invitation is accepted, then Australia can expect trade-offs for its contribution in terms of design and construction contracts. At the same time, Australian astronomers have been anxious to retain eminence in Southern Hemisphere astronomy through a share in the VLT, which will be at a scale and altitude higher than possible on their own continent.

Cook has not given any public explana- tion of why the recommendations of the expert committees were apparently ignored by the government in December. But a spokesman said the government had been reluctant to spend such a large proportion of the facilities fund on a single project, or on one based overseas.

In the lead-up to the election, however, the minister appears to have been embarrassed by adverse public comment on the December announcement. Within two days, he was having meetings with astronomers, promising them that he would seek extra funds to resuscitate the ESO plan.

Negotiations with ESO took place early in February, when Jeremy Mould, director of the Mount Stromlo and Siding Spring Observatories, and Michael Pitman, the government's chief scientist, visited ESO headquarters at Garching in Germany. They returned to Australia with a draft agreement two days before Cook's speech.

Cook has now exchanged letters with ESO, and has set up a four-man group to negotiate the details, as well as making a public commitment to funding. $\mathrm{He}$ also promised to contact his opposite number, Robert Hill, to seek the coalition's agreement to making the ESO deal a bipartisan policy.

Astronomers have also been keeping their lines open to Hill, given the possibility of a change of government in the elections. Hill confirms that under a coalition government, the negotiations on Australian participation in the project would continue.

Ironically, the very international aspects that had worked against the ESO link last year are now counting in its favour. Cook said last week that he wants to back more new projects, including a centre of excellence in radioastronomy to serve the Asia-Pacific region, in which Australia is seeking a leading economic and political role, and an infrared telescope in Antarctica.

The December decision reflected lack of interest among Australian politicians in supporting European links at a time when they saw the future of trade and links in science and technology as lying in the Asia-Pacific region. But the route to wider opportunities for Australian science is now back in favour.

But a shadow still hangs over the announcement. No new agreements can be concluded by the government as caretaker during an election campaign, after which the government or minister may change. No matter what the outcome of the election, the country's economic difficulties could still provide whichever party gains power with justification for slashing expenditure.

Peter Pockley

\section{Review panel cancels meeting as gene therapy proposals fall}

Washington. What had previously been a regular stream of proposals for innovative human gene therapy experiments has dried up, prompting an advisory panel of the US National Institutes of Health (NIH) to cancel its next quarterly meeting.

But members of the Recombinant DNA Advisory Committee (RAC) deny the drop is related to a highly critical report on gene therapy commissioned by Harold Varmus, the director of NIH, and delivered to him in December (see Nature 378, 655; 1995).

"It's too early to talk about a trend," says LeRoy Walters, acting director of the Kennedy Institute of Ethics at Georgetown University in Washington DC, and acting chairman of the committee. "We could find that [the] number of protocols submitted rebounds."

The report, prepared by a panel chaired by Stuart Orkin of Harvard Medical School and Arno Motulsky of the University of Washington, warned researchers against "overselling" gene therapy, and called for more emphasis on basic research.

Walters conceded that the need for researchers to "read and discuss" the report may have slightly dampened applications to the 25-member RAC, which has cancelled its March meeting on the grounds that it does not have any protocols to review. But he suggests that heavy snowfalls, US government shutdowns and the holiday season are likely to have played larger roles.

Nelson Wivel, executive secretary of the RAC, says that a new, streamlined application procedure has also contributed to a mistaken perception that gene therapy applications are down. Since July 1995, gene therapy protocols that are not substantially original are forwarded directly to the Food and Drug Administration, bypassing the RAC.

What has plummeted, says Wivel, is not the total number of applications but the number being subjected to full RAC review. For example, at its December quarterly meeting, the RAC reviewed just one original protocol, namely one for treating ornithine transcarbamoylase deficiency, a rare genetic disorder involving urea metabolism.

Some researchers say that the decline in original protocols is not surprising because the limits of current technology are being reached. "It's exactly what you'd expect," said Malcolm Brenner, director of the cell and gene therapy programme at St. Jude's Children's Research Hospital in Memphis, Tennessee. "As certain technology becomes available, it gets developed to a certain level. Then there's a pause while everybody moves on to the next level. That's beginning to happen."
Meredith Wadman 